\title{
2. Madness as Communal Threat
}

\begin{abstract}
The narrative structures used in remission letters demonstrate how the family advocated for the mad person by constructing stories about the crime, but also reveal details about the person's entire life. The evidence provided for mental illness earlier in the person's life was often idiosyncratic, and sometimes the narratives tried to provide logical linkages between the earlier behavior and the ultimate crime of the mad person. These individual narratives reveal a wide spectrum of beliefs about what caused madness and what kinds of behaviors and criminal acts were coded as mad. Although each narrative was distinct, a clear pattern emerges whereby the actions of the individual identified as mad disrupt familial and communal bonds.
\end{abstract}

Keyterms: Narrative, Crime, Insanity Defense, Community

In October of 1380 , one month after Jehan de Moustier murdered his father, his 'close family" sought a letter of remission for him. Jehan was in prison in the town of Saint Denis, from which the family traveled the short distance of twelve and a half kilometers to the royal capital, where Louis of Anjou was serving as regent for the eleven-year-old Charles VI. With the help of the notary P. de Disery, the family composed a letter explaining Jehan's crime and asking that he be pardoned. While in Jehannecte Troppés narrative it is not clear whether her family had already decided to characterize her actions in terms of madness before meeting with the royal notary, in this particular case the family had already publicly identified Jehan de Moustier as mad. The remission letter explains that Jehan's condition had been recognized as madness by the local authorities, referring to a previous intervention by the Marshall of Pontoise, who provided the family with

1 AN JJ 118 fo $18 \mathrm{v}$ no 18 : 'amis charnelx'. For a discussion of the meaning of 'parens et amis charnels', see Gauvard 1991, vol. 1, pp. 643-651.

Pfau, A., Medieval Communities and the Mad: Narratives of Crime and Mental Illness in Late Medieval France. Amsterdam: Amsterdam University Press 2021 DOI: 10.5117/9789462983359_CHO2 
chains to help them control Jehan. ${ }^{2}$ In the letter the supplicants and the notary considered the events of his life to highlight evidence of madness and construct a convincing narrative of his patricide that would then be read out in the local courts. Such a narrative had to be sufficiently compelling to be accepted and confirmed by both the king's council and the adverse party, who was given the opportunity to challenge the letter when it was read aloud by the local judge. ${ }^{3}$

Most remission letters sought to construct a coherent narrative of a particular crime. Letters composed on behalf of the mad, in contrast, generally sought to establish that the individual was indeed mad, and thus provided a narrative of a life. These biographies in miniature either involved evidence of an ongoing struggle with madness over the course of the individual's life or attempted to demonstrate the way madness caused the person to behave in unexpected ways, rupturing a recognizable identity that was constructed in part through kin and communal ties. This chapter explores the narrative structures of these letters, looking particularly at the ways in which the composers of these letters saw the crimes committed by the mad as particularly threatening to kin and community.

It is important to remember that letters of remission were joint efforts, co-authored by the supplicants and the royal notaries who recorded them. It is possible to speculate on what content was contributed by which 'composer'. ${ }^{4}$ Clearly the royal notary who recorded the letters in the chancery archive was responsible for the formulaic language invoking the king's grace and mercy. The narrative of the crime and the life of the accused were at least in part supplied by the supplicants, who may have been responding to appropriate questions posed by the notary. While some letters for mad people who had recovered their sanity follow the more general pattern of remission letters sought by the individual who committed the crime, the majority was sought through the cooperative effort of the family as the mad person languished in prison awaiting trial or was detained due to the disease. The supplicants may even have consulted with a legal expert before coming to Paris in order to establish whether the case was eligible for remission. Once a letter of remission was received it had to be read aloud in the presence of the adverse party. Since the other side was granted the

2 AN JJ 118 fo $18 \mathrm{v}$ no 18.

3 Texier 1984, p. 9, p. 263 and pp. 324-338. Texier notes that this right to challenge did not negate royal authority. Although the victim could appeal the remission letter, it had to be done in front of a royal judge, thereby reaffirming royal judiciary power.

4 Davis 1987, pp. 15-19; Gauvard 1991, vol. 1, p. 66. 
opportunity to dispute the narrative contained in the letter, it is conceivable that they also were involved in the composition. The supplicants may have come to an agreement with their adversaries before deciding to invest time and money in a trip to Paris to seek the king's pardon. Thus, many different minds were involved in defining and indicating madness within these letters.

This group, made up of legally-trained notaries, legal experts, supplicants seeking remission, and in some cases the adverse party, can be imagined in terms of a 'textual community', formed around a text, where one or more literate individuals provided access to that text for the larger, illiterate component. 5 The literate and knowledgeable experts provided a framework within which the information supplied by the supplicants could be given shape and meaning. As noted in the introduction, the invocation of madness was not common, but it does appear rarely but consistently over the one hundred fifty year period under examination. ${ }^{6}$ Unlike the more common crimes, it seems that notaries did not develop a standard form for writing about crimes committed by the mad. Nevertheless, the notaries' knowledge about law codes gave them an awareness of the benefits and the hazards of establishing that a person was mad when he or she committed a crime, 7 as well as a general concept of what kind of evidence was necessary to demonstrate madness. Together with the supplicants, the notaries were able to construct a narrative that reflected on the life of the individual, providing convincing evidence of madness and building to the moment of the criminal act.

These narratives provide only one side of the story, although it is possible that the adverse party agreed to the pardon beforehand and thus had some control over the content of the letter. Nevertheless, remission letters conceal multiple alternative narratives that cannot be recovered, at the same time as they reveal a complex and compelling story. Bearing in mind that these

5 Brian Stock coined this term as a way of describing heretical communities in Europe, that centered around an interpreter who read aloud from texts. I have altered his use of the term: whereas the textual communities he describes were centered around pre-existing texts, the textual communities I am imagining are centered around the creation of a new text. See Stock 1990, p. 13.

6 On average, letters about madness appear in one percent of the total remission letters, and in the books that were fully examined they never exceeded three percent. On the other hand, only two of the thirty-five books searched yielded no references to madness.

7 Roman law established that mad people should not be held responsible for committing crimes. However, a number of French customals called for the mad to be restrained so as to prevent them from committing crimes. Some remission letters reflect these laws. See, for example, AN JJ 118 fo 18 v no 18 (in 1380) and AN JJ 173 fo 33 vo 63 (in 1425), edited in Le Cacheux 1907-1908, pp. $181-183$. 
letters were carefully constructed by a group of composers, and the resulting narrative had to be acceptable to all parties involved, how was Jehan de Moustier's particular narrative constructed? What mechanisms did his close family and the notary use to establish his madness and demonstrate that he could not be held responsible for the death of his father? What types of crimes were associated with madness and what can that tell us about how madness was understood?

\section{Reconstructing a Life Narrative}

Jehan de Moustier's letter of remission states that during the month of May 1379, he began to exhibit behaviors that his family interpreted as madness. The composers of his letter claimed that he 'was utterly mad as is apparent by his crimes'. ${ }^{8}$ First, he 'took himself to the woods and the fields, whistling to the birds and running. He remained there for two or three days such that he should perish from hunger, and the good people who found him brought him back'. ${ }^{9}$ After Jehan had repeated this behavior a few times, his father, Perrim, decided to take him to the shrine of Saint Titenerd at Gournay, north of Saint-Denis. ${ }^{10}$ At the saint's shrine, he was chained up and left to await God's mercy. Escaping from those chains, he was recaptured and held with two sets of chains, but he escaped from those as well, demonstrating an abnormal strength.

When Jehan returned from the shrine, he was better for a time, but at the beginning of Lent in 1380 he began again to exhibit mad behavior, and the Marshal of Pontoise provided a particularly heavy set of chains to his father so that he could be controlled. ${ }^{11}$ When he broke out of that set, 'a thing that did not seem possible for a man to do', his father refused to rechain him. ${ }^{12}$ Once freed, Jehan proceeded to kill a heifer during the first week of Lent, which his family referenced as further proof of his madness. His final and

8 AN JJ 118 fo 18v no 18: 'soit pur fol comme il est apparu par ses crimes'.

9 AN JJ 118 fo 18v no 18: 'sen aloit par bois et par champs sifflant aus oiseaux coursent en demourant deux ou trois jours tant que il perissoix de faim et le ramenoient les bonnes genz qui le trouvoient'.

10 Neither I nor anyone with whom I have discussed this letter have ever heard of a Saint Titenerd. Indeed, the parish church in Gournay-sur-Marne is dedicated to Saint Arnoult.

11 In this case, the mareschal was most likely 'an officer of a court of law responsible for the custody of prisoners and for the keeping of order, and frequently entrusted with the keeping of a prison' as defined by the Oxford English Dictionary, which cites the earliest reference around 1300 .

12 AN JJ 118 fo 18v no 18: 'qui ne sembloit pas possible chose afaire a homme'. 
most serious crime also centered on food production: during a particularly hot week in September of the same year, the town mandated that anyone wanting to make bread needed to allow it to rise on Wednesday night and knead it on Thursday. However, Jehan decided to begin making the bread at nones (around 3 p.m.) instead of waiting until the late evening, because he wanted to knead the bread that night, not the next day. Perrim prevented him from doing so on Wednesday, but the next morning asked him if he was going to knead the bread. Jehan, in a fit of rage brought on, according to the composers of his letter, partly by his madness and partly by anger that he had not been allowed to knead the bread the night before, picked up 'a stick called a "basuche" with which one trims the vines"13 and hit his father with it until he died. When the local justice arrived and told him 'you have killed your father', Jehan responded 'he was only my father according to whispers' ${ }^{14}$ The composers of Jehan's letter explained that they did not merely fear for his life, but also for his immortal soul, since 'if he were to suffer death for this, he does not have the memory or sense to recognize his creator.'.5

The composers of this letter did not specify a primary cause of Jehan de Moustier's madness, but it is clear they made connections between the events they noticed as unusual and the ultimate crime he committed. In beginning to describe his madness, the letter composers emphasized that it was apparent from his 'crimes'. Although his final 'crime' was the murder of his father, his earlier acts appear less serious than that, particularly to a modern eye, but the composers of Jehan's remission letter viewed these other events as 'crimes' as well. In this letter, criminal acts were caused by madness, and simultaneously provided proof that the criminal was mad, creating a circular logic that went uncontested. While there is an intimate connection between crime and madness in these remission letters, there was no single definition of what constituted a mad crime, which makes these texts so interesting. In Jehan de Moustier's case, his mad behavior followed a particular and distinct pattern that centered on food production and consumption.

13 AN JJ 118 fo 18v no 18: 'un baston appelle basuche dont on prongue les vignes'.

14 ANJJ 118 fo 18v no 18: 'tu as tue ton pere il dist que il nestoit son pere que dans oreille'. I have chosen to translate 'dans oreille' here as 'according to whispers' because it resonates better than 'in the ear'. I have not been able to find proof that this is, in fact, a good colloquial translation, despite searching for a similar usage elsewhere, so I have chosen not to fully pursue this particular episode in Jehan de Moustier's letter, although the inability to recognize familial relationships does seem to be an important facet of medieval conceptions of madness.

15 AN JJ 118 fo 18v no 18: 'se pour ce il souffroit mort il navroit memoire ne senz de recognoistre son createur'. 
From Jehan's letter it is possible to extract a compelling narrative of escalating mad behavior. Jehan's first episode of madness involved an inability to care for himself, as he ran through the fields and woods and did not eat anything for several days. The trope of the mad person running in the fields would have been familiar from the biblical story of Nebuchadnezzar and literary figures such as the Arthurian heroes Yvain and Lancelot. Running in the fields was in fact used as a proof of madness in some other remission letters, ${ }^{16}$ but the mention of a lack of sustenance was unusual. Where the biblical figure Nebuchadnezzar ate grass ${ }^{17}$ and Chrétien de Troyes' Arthurian knight Yvain ate raw meat, ${ }^{18}$ Jehan de Moustier engaged in 'unholy anorexia'. ${ }^{19}$ Indeed, when he was finally captured and returned to the village, his family asserted that he was nearly dead from hunger. Jehan's starvation to the point of death strongly suggested that his inability to feed and care for himself threatened his own life.

This reference to Jehan's excessive starvation is particularly interesting in light of Jean Gerson's contemporary attempts to limit what he saw as the excessive fasting that many female mystics were practicing, as discussed above. ${ }^{20}$ As he explained, the dangers of excessive fasting are physiological. Starvation can cause mania, rage, or melancholy to such an extent that visions occur, and create a false image of reality. Gerson's theory connecting food consumption to madness may have been influenced by a wider social

16 For example, a sorcerer made people run through the fields because of madness in AN JJ 187 fo 89 v no 173 (in 1457) and AN JJ 208 fo 11 no 20 (in 1480). A young boy who was guilty of theft was similarly known to run through the fields due to his madness in AN JJ 196 fo 192 no 307 (in 1470), as was a man who later committed murder in AN JJ 229 fo $22 \mathrm{~V}$ no 44 (in 1497).

17 Daniel 4:30.

18 The consumption of uncooked food is held up as a proof of madness in Chretien de Troyes' tale. See Chrétien de Troyes 1994, p. 274.

19 Here I am playing on Rudolph Bell's concept of 'holy anorexia' in Bell 1985. His work is controversial, and Carolyn Walker Bynum has done much to challenge his perspective, arguing that control of food was a way in which women empowered themselves. See Bynum 1987. It is also necessary to note the more recent contribution to this debate by Nancy Caciola 2003 . Caciola argues that Bynum and others have overemphasized the hagiographical views of the confessors who wrote these women's lives. She contends that any examination of these women's actions has to take into account the fact that they were seldom sanctioned by the church, and that the larger population viewed them with serious suspicion. However, Caciola focuses solely on Gerson's distinction between divine and demonic inspiration. While this was admittedly Gerson's main focus, his acknowledgement of mental disturbance is also significant.

20 Gerson 1998 , pp. 334-364. Although there is no direct evidence that royal notaries were interested in Gerson's theological works, some of them were involved in epistolary communication with him in the debate over the Roman de la Rose, and may have been aware of his other projects. Certainly the notaries, as educated men living in Paris, can be credited with an awareness of the larger discourse around discernment in this period. 
belief. The composers of Jehan de Moustier's letter seemed to believe that his madness caused him to starve himself, thereby exacerbating his madness and forming the same dangerous cycle.

In a second episode, after a period of sanity, Jehan de Moustier killed a heifer during Lent. This was doubly problematic, and simultaneously violated both implicit and explicit rules governing animal slaughter in a medieval village. A heifer is a cow that has not yet calved and Lent was a time when no one was supposed to eat it, so the slaughtered cow would be wasted. A cow, but especially a cow that could be expected to produce other cows, was a valuable commodity for a household. There is evidence from the records of medieval estates, as well as archaeological evidence from the waste deposits of both estates and cities, suggesting that young, female animals that had not yet reproduced were not slaughtered, even by the wealthy. ${ }^{21}$ Similarly, although the major period for slaughter, especially of pigs but also of cows, was in late fall and early winter, animals were generally killed and taken to market in towns and cities throughout the year, except during Lent. ${ }^{22}$ The slaughter of this particular animal at this particular time, according to the composers of the letter, provided proof of the return of Jehan de Moustier's madness, which in this case was characterized as prodigality. His wasteful behavior threatened his family's food store, since he killed the cow before it had produced a new generation and when it could not be consumed.

In the final episode recorded in the letter, he killed his father over a dispute about when to knead bread. In this case, Jehan de Moustier's desire to knead the bread early was a threat to the community as a whole. The heat of the summer had caused fevers and illness in the town, and the decision to bake bread in the communal oven on a certain day and at a certain time was intended to protect the community from the excessive heat of baking. ${ }^{23} \mathrm{Jehan}$ 's

21 Kathleen Biddick 1989 used records from Peterborough Abbey in England and found, as might be expected, that female cows were not slaughtered until after they had reproduced, although males might be slaughtered young. See also Doll 2003, p. 283. Doll looked at digs from towns, castles, monasteries, and sewers in Germany from the thirteenth to the seventeenth centuries, and found that seventy to ninety percent of slaughtered animals were two years old or more.

22 In a study of butchery records in two Italian towns, Gillian Clarke found that no animal's meat was sold during Lent. Clarke 1992, especially the tables on pp. 78-79. December was the month of slaughter in medieval calendars, and the butchers' records studied by Clarke suggest there was an increase in late fall and early winter, but there does not seem to be a single month for slaughter. For the calendars, see Henisch 1999, p. 127. Interestingly, she sees a shift in the late fifteenth century towards images of buying meat in town, instead of images of slaughtering, but nevertheless the image of the animal 'harvest' is generally in December.

23 For more on communal ovens, see Bloch 1967, p. 153. 
attempt to knead the bread early would have ruined the family's bread, but the further implications of his desire to bake the bread at an inappropriate time would have been even more serious in the eyes of his neighbors. Clearly, Jehan's inability to comprehend both the simple and the complex relationships to food that were apparent to everyone else in his village led to serious problems, for his own health and that of others. The narrative of food production and consumption builds as the 'crimes' build, to a climax where Jehan de Moustier threatened the community's welfare and ultimately killed his father.

In attempting to comprehend a crime that appears inexplicable, the composers of remission letters for the mad reinterpreted the past of the individual, seeking a point of rupture where the person moved from sanity to madness. This approach is similar to that used in hagiographical writings, where the saint's later sanctity is allowed to bleed back into their childhood. ${ }^{24}$ It is clear in the letter for Jehan de Moustier that madness was inscribed through a certain pattern of behaviors that was recalled as constituting a rupture between expected and actual acts. The retrospective consideration of Jehan's actions in terms of his final crime allowed the composers of his remission letter to find a rationale for his behavior. The ways in which madness is described and determined is embedded within the rhythm of medieval village culture, where food production and consumption were central to everyday life. The composers of Jehan de Moustier's remission letter did not concern themselves with medical or psychological causes of madness; rather their description of his inexplicable behavior sought a source for madness in terms of social interactions. By 'making sense' of the 'insensible' through the development of a clear pattern only visible in retrospect, the composers created a narrative whereby Jehan's final crime was comprehensible. In turning now to the larger corpus of letters, this chapter will consider how the crimes committed by the mad were understood as particularly damaging to the community.

\section{Moments of Rupture: Crimes Against the Family and the Community}

As discussed in Chapter One, remission letters mediated between popular beliefs about madness held by the family telling the story and elite knowledge held by the notary writing the letter. In a process of cooperative composition,

24 Many of the saints in Jacobus de Voragine's Golden Legend, for example, are described as having exemplarily holy childhoods. Jacobus de Voragine 1993. 
the letter was written both for the king's council, who had to ratify it, and for the adverse party, who had to approve its content in front of the judge. ${ }^{25}$ Thus, the information contained had to be comprehensible on many levels. Family members advocated for the mad by attempting to understand and explain madness, both as it existed inside the body and as it was externally performed. ${ }^{26}$ In an effort to describe behavior they perceived as a sign of madness, the composers of remission letters wrote life histories of the mad, explaining actions in light of or in extreme contrast to the actions of madness.

Madness is often seen as the rupture of an identity, constructed through kin and communal ties, that can be perceived through certain actions signaling a shift between the person's sane behavior and mad behavior. Sylvia Huot, in discussing madness in medieval French literature, argues that

[s]anity is the perfect concordance of a symbolically constituted identity, the performance through which that identity is staged, and the body that gives it material form; and madness can be understood as the dissolution of that construct. The onset of madness results in an incoherent relationship between body, performance, and social identity. ${ }^{27}$

These 'incoherent relationships' are defined and explored in remission letters as they are in the literary texts Huot references. The causes of madness and the resultant behavior of the mad were both interpreted in terms that the family members composing the letter could access, and these terms described an individual who acted in a way that was no longer recognizable as part of the social identity the mad person had previously enacted. Madness was an observable phenomenon, defined through social interactions and perceptions. As is clear from Jehan de Moustier's letter, which revolved around food consumption and production, the specific patterns of individual cases were focused within their particular narrative. The letters all represented the individual's madness as a danger to the surrounding community, occasionally just at the moment of the crime, but often for an extended period beforehand.

25 Gauvard 1991, vol. 1, p. 67.

26 In talking about the performance of madness I am not trying to suggest these people were falsely claiming to be insane, but rather highlighting the fact that the interiority of madness as a disease can never be accessed, leaving only the external signs of madness as an indicator of the internal state. Thus, madness is performed and interpreted. See Caciola 2000, pp. 287-29o for a discussion of these ideas as they relate to spirit possession.

27 Huot 2003, p. 182. 
Although there was no single required pattern for telling a narrative of mad crime, certain types of information were included in most of these letters. The kinds of narrative arcs used in the letters inscribed a number of shared beliefs about madness. Remission letters about the mad reflected the same kinds of conflicting images of madness that appeared in the legal discourse of the time. Mad people were simultaneously feared for the threat they represented (and most often, in the letters, had already carried out) and considered in need of protection from the repercussions of their actions. ${ }^{28}$ The most common fear that remission letters revealed was that mad people would attack family members or themselves. The crimes of the mad were focused inside the household, rather than outside, which distinguished them from the usual crimes for which remission was sought. This may reflect a cultural perception of intrafamilial crime as more serious than interfamilial crime. Indeed, one of the few crimes that were theoretically considered 'irremissible' was parricide, showing continuity with the Roman perspective that saw the murder of a family member as particularly troublesome. ${ }^{29}$ Not all remission letters for parricide referred to madness as a mitigating factor, ${ }^{30}$ but there is a suggestive pattern to the types of crime viewed as outside the realm of reason.

Every letter of remission began with the implicit acknowledgement that a crime had been committed, but the revelation of the crime was delayed until the culmination of the narration. That said, some letters foreshadowed the nature of the crime through particular phrases. For example, often

28 Philippe de Beaumanoir, for example, maintained: 'Those who are insane [forsené] should be bound by those who must guard them and everyone must help do this to avoid the damages that might come from them, for they could quickly kill themselves and others'. Philippe de Beaumanoir 1970-1974, vol. 2, ch. 52, paragraph 1575: 'Cil qui sont forsené doivent estre lié par ceus qui les doivent garder et chascuns doit aidier a ce fere pour eschiver les damages qui par aus pueent venir, car tost ociroient aus et autrui'.

29 Mommsen, Krueger, and Watson 1985, vol. 4, p. 822, book 48.9: 'Truly, if anyone kills a parent in a fit of madness, he shall not be punished, as the deified brothers wrote in a rescript in the case of a man who had killed his mother in a fit of madness; for it was enough for him to be punished by the madness itself.' 'Sane si per furorem aliquis parentem occiderit, inpunitus erit, ut diui fratres rescripserunt super eo, qui per furorem matrem necauerat: nam sufficere furore ipso eum puniri.' Esther Cohen argues, on the basis of rhetoric about remission letters in royal charters rather than on the basis of the content of remission letters themselves, that 'genuinely heinous crimes (such as parricide) neither deserved nor received pardon'. Cohen 1993, p. 50. Clearly, the ideal did not match up to the real regarding parricide.

30 See the tables in Gauvard 1991, vol. 2, pp. 614-620. 
an individual was introduced as 'the late ${ }^{31}$ so-and-so, generally (although not always) indicating that that person would lose his or her life in the course of the narrated events. Indeed, often a clear indication of suicide was the linkage of 'the late' with the name of the individual on behalf of whom the remission was being sought. The particular types of crimes committed by mad perpetrators signaled a departure from expected behavior, though sometimes details recalled from the past that established the onset and development of the perpetrator's madness foreshadowed the ultimate crime, as the letter for Jehan de Moustier demonstrates. All remission narratives were constructed around the moment of a crime. Although the accused perpetrator did not admit his or her guilt in every case, nevertheless a description of the crime of which the supplicant was accused appeared in every letter. Every type of crime committed by a person labeled as mad in remission letters also appeared in other letters committed by a sane person. However, there are patterns to the crimes associated with madness that go beyond the surface of the act committed. These were acts that were particularly damaging to the family or the community of the mad person. The association of madness with crimes targeting people or things that should be protected has also been shown by Michael MacDonald in his study of seventeenth-century England..$^{22}$ These crimes were not described as random, but rather as disruptive of important social and familial ties.

Perceptions of madness both affected and were affected by the particular crimes associated with mad criminals. No crimes were considered exclusively 'mad crimes.' ${ }^{33}$ However, while the basic crime is the same, the details in the letters reveal particular ways in which crimes committed by the mad were distinctive. The majority of these crimes acted against the mad person's own identity or against his or her family. ${ }^{34}$ These types of crimes were troubling to the family and the royal notary who worked together to compose these letters, and this discomfort translated itself into the description of the mad person and the crime committed.

31 Feu or feue.

32 MacDonald 1981.

33 Indeed, it is worth pointing out that many of these crimes were those Gauvard refers to as 'stereotypes of serious crimes'. See Gauvard 1999, pp. 1-48.

34 Identity is being constructed through these letters in terms of the individuals' relationship to others, particularly their participation in groups, specifically family and community. I am basing this partly on Caroline Walker Bynum's description of identity construction in the twelfth century, Bynum 1984. See also Heers 1977, pp. 1-15. 
Table 2 Crimes of the mad

\begin{tabular}{lllll}
\hline Crime & Number & Percentage of Total & Male & Female \\
\hline Arson & 9 & $5.8 \%$ & 5 & 4 \\
Bestiality & 3 & $2 \%$ & 3 & 0 \\
Blasphemy 35 & 5 & $3.2 \%$ & 5 & 0 \\
Cause of Murder & 8 & $5.2 \%$ & 1 & 7 \\
Infanticide & 7 & $4.5 \%$ & 1 & 6 \\
Murder & 35 & $22.5 \%$ & 29 & 6 \\
Rape $^{36}$ & 3 & $2 \%$ & 3 & 0 \\
Suicide & 18 & $11.6 \%$ & 8 & 10 \\
Theft & 27 & $17.4 \%$ & 19 & 8 \\
Treason & 11 & $7 \%$ & 11 & 0 \\
Victim of Crime & 20 & $13 \%$ & 13 & 7 \\
Other & 9 & $5.8 \%$ & 6 & 3 \\
Total & 155 & & 104 & 51 \\
\hline
\end{tabular}

\section{Murders of Family and Neighbors}

The crime of murder was disruptive to a community, regardless of the mental state of the perpetrator. Murder had the potential to spiral into a feud with an extended kin network and sometimes the entire neighborhood taking sides. ${ }^{37}$ Remission letters, read out loud in front of the adverse party and open to objection, could play a role of mediation between the two sides, clarifying the case from the perspective of the criminal and attempting to temper the anger of the surviving family. Indeed, murder was the most common crime for which to seek remission in general. Claude Gauvard, in her study of remission letters, argues that when an attempt was made in 1400 to curb the number of remissions being granted, the letters became more focused on homicide as the particular crime for which remission

35 Charles VI passed a number of laws against blasphemy during his reign. The first was recorded in Parlement in 1397. Stein 1908, 153-154. When he reconfirmed the law in 1415 , the mad king included language suggesting that the problems of the realm might have their roots in the blasphemy of the people, saying 'it may be for this cause that many great disgraces and inconveniences have come and come every day in diverse ways, to Us and to our said subjects' ('puet estre que à ceste cause pluseurs grans esclandres \& inconveniens qui sont avenuz \& aviennent de jour en jour en diverses manieres, sur Nous \& nosdiz subgiez'). Vilevault and Bréquigny 1763,243 .

$3^{6}$ There are very few rape cases that mention madness, though there are considerably more rape cases in letters of remission as a whole. For more, see Gauvard 1991, vol. 1, 330-339; Prevenier 1990; and Prevenier 1999.

37 See for example, Meyerson 2004; Muchembled 1989; and Muir 1993. 
should be granted. ${ }^{8}$ Whereas my own numerical study of remission letters suggests that Gauvard is mistaken in her assessment of the impact of this regulation, ${ }^{39}$ homicides certainly did account for a large percentage of the letters from the time when they were first instituted, and the percentage increased over time. Of the 155 letters about mad people examined for this study, thirty-five provided remission for murder, making up the highest percentage..$^{40}$ The narratives of murder cases involving mad people were different from the more common passionate, drunken murders, however. In most cases, mad people murdered friends or family members. While these types of murders could be committed by sane people, the pattern is still suggestive of a larger concept of the relationship between madness and crime. Roman law established that mad people should not be held responsible for parricide, creating a direct link between madness and intrafamilial murder. ${ }^{41}$ Indeed, in these remission letters mad people seldom appeared lashing out at complete strangers, and when they did it was usually in the context of the stranger seeking remission for having killed the mad person, rather than the other way around..$^{2}$ The murder of close companions and family members was seen as a particularly disturbing act, and, in cases where there were other recognizable factors that contributed (if only in retrospect) to the medieval image of madness, such a murderer could be viewed as mentally disturbed..$^{43}$

In eighteen of the cases of murder by a mad person, the victim was a member of the murderer's family. Most of these involved the murder of a spouse, although there were also several cases of murder across generations, where the victim was the father, mother-in-law (but never the

38 Gauvard 1991, vol. 1, p. 64 .

39 Gauvard 1991 uses the numerical decrease to make her argument, but remission letters remain as the same percentage of total chancery business, suggesting it is not a decrease in the granting of remission that is being marked but a decrease in the use of the chancery. Given that this decrease occurs during a period of civil war and governmental instability due to Charles VI's madness, it seems more likely that this general upheaval, rather than a targeted effort to limit remissable crimes, caused the numerical decrease in remissions granted.

40 Wendy Turner also found that homicide 'was the most commonly prosecuted crime involving the mentally incapacitated' in England. Turner 2013a, p. 114.

41 Mommsen, Krueger, and Watson 1985, vol. 4, p. 822, Book 48.9

42 For example, AN JJ 89 fo $142 \mathrm{v}$ no 340 (in 1357); AN JJ 172 fo $113 \mathrm{v}$ no 221 (in 1422); and AN JJ 219 fo 132 no 216 (in 1488).

43 Both Claude Gauvard and Barbara Hanawalt have looked at murders between relatives in France and England, respectively. See Gauvard 1991, vol. 2, p. 573 for her discussion of violence between married couples, which she found to compose only $2 \%$ of cases. Hanawalt notes that '[a]bout a third of the intra-familial homicide cases tried in gaol delivery were committed by the insane'. Hanawalt 1974, p. 11. 
mother), father-in-law, or uncle. ${ }^{44}$ These murders most often occurred in the household, combining both relationships and spaces where murder was jarringly unexpected. Unlike the public tavern, where drunken arguments could lead to accidental murder with the daggers and knives carried by most people ${ }^{45}$ murders in the household were seen as disruptive. Even the weapons chosen carried added significance. Household murderers picked up whatever weapon happened to be lying around, often an axe used to chop wood or a stick with iron on the end of it, such as a utensil used to trim vines or a hoe. The letters always specified the quotidian use of these household items, clearly indicating that the crime was not premeditated and that the murder weapon was easily at hand, and not a weapon, such as a sword, intended for use only in violence approved by the king. ${ }^{46}$

Several of the murder cases took place in the middle of the night, a common time for murder according to other studies of medieval crime. ${ }^{47}$ However, these murders did not follow the usual pattern of nighttime homicides that took place outside. Rather, most took place in the household, and often between people sleeping in the same bed. In 1392, for example, Pierre le Bagnaudel, who 'was often furious, lunatic and out of his memory', ${ }^{8}$ went to bed one Sunday night, and woke up again in the early hours of Monday morning in a state of madness. He beat his wife with a hoe, then got back into bed beside her and slept until morning, still holding the murder weapon. Pierre le Bagnaudel's lack of recognition of his actions and the fact that he remained beside the mortally wounded body of his wife, holding the murder weapon in his hand, rather than running away, were pointed out by his family as further indications of madness. ${ }^{49} \mathrm{~A}$ similar story from 1425, discussed above, described the actions of Jehannecte Troppé, who woke up in the middle of the night seeing visions that led her to beat her husband. When she went back to bed, her husband woke her again and she was shocked when she lit a candle and saw his wounds. The letter specifies that she cared for her husband's wounds 'not knowing she had done the said

44 Those cases where the victim is the mad person's child will be treated separately, under infanticide, since such cases were categorized separately under medieval legal traditions.

45 Gonthier 1992, pp. 113-115.

46 The letters feel rather like a game of Clue as a result. 'It was Jehan de Moustier in the kitchen with the stick used to trim the vines'.

47 Nicole Gonthier notes that curfews were instated because night was seen as a time that 'peut cacher les criminels et favoriser leurs intentions perverses'. Gonthier 1998, pp. 53-55.

48 AN JJ 143 fo 108v no 207: 'souventeffoiz est fureur lunatiques et hors de son memoire'.

49 Voluntary exile after committing a crime was an accepted, and in some cases even expected, response. 
deed'. $5^{0}$ The marriage bed, unlike the public street, was a location in which violence was unexpected and disturbing, and this type of violent attack on a spouse who was sleeping ruptured the safe haven of the household.

Spouses were not the only possible victims of violence within the household. In 1376, the wife and family of Pierre de Solente explained that he was a seventy-year-old man who had suffered for about a year from the 'fragility or diminution of his body and of his sensuality' to such an extent that he had 'become entirely idiotic and also as if furious and out of his correct thoughts'. ${ }^{11}$ Initially, his family was concerned that he would commit suicide by hanging or drowning himself, and his wife was careful to watch over him. However, one morning she left him sleeping with their nine-year-old son, Thomassin, so she could go to the market. Thomassin refused to get up when his father asked him to do so, arguing with his father and crying. In response, much like Jehan de Moustier, Pierre went significantly beyond what might be reasonable. In the letter, they explained he was 'moved by his madness, by evil temptation, seduced by the enemy of human creatures' such that he grabbed his son by the head and cut his throat with a knife..$^{2}$ Afterwards, Pierre tried again to drown himself but was stopped by his neighbors and his wife who had returned home. In contemplating his crime, the composers of his letter noted that he had forgotten the natural love that he must have for his said son'.53 Pierre's murder of his son Thomassin clearly disrupted his community's expectations.

Even when the victim was not a member of the family, narratives that chose to deploy the language of madness were often about inexplicable and unexpected acts of violence that posed clear threats to the community. The story of Ysabeau, daughter of the Montpellier merchant Raymon Sarvallier, recorded in a letter from 1408 , is a clear example of this. In many ways, Ysabeau's behavior ruptured social expectations, and it was this behavior that first caused her community to identify her as someone who 'does not have good, natural sense'. ${ }^{4}$ During her first marriage to Naudin de Moscre, the son of the Sire de Moscre, Ysabeau only lived with her husband for a short time, and instead moved around her friends' homes without the

50 AN JJ 173 fo 33v no 63. Edited in Le Cacheux 1907-1908, vol. 1, pp. 181-183: 'non sachant avoir fait ledit fait'.

51 AN JJ 110 fo 125 no 108: 'fragilite ou diminucion de son corps et de sa sensualite soit devenu tout ydiote et aussi comme furieux hors de sa droit pensée'.

$5^{2}$ AN JJ 110 fo 125 no 108: 'meu en sa forcenerie par mauvaise temptacion seduit par lennemj dumaine creature'.

53 AN JJ 110 fo 125 no 108: 'avoit oblie lamour naturelle quil devoit avoir a son dit filz'.

54 AN JJ 163 fo 130 no 229: 'quelle navoit pas bon sens naturel'. 
permission of her husband. After Naudin de Moscre's death, she married Guille Gauguin, and in the eleven years since her second marriage she had continued her peripatetic lifestyle, staying 'in the home of her mother and with her other friends by day and by night [...] without the permission and desire of her said husband'.55 In some ways, then, Ysabeau's behavior followed the general pattern of a bad wife, though the composers of the letter written on her behalf were quick to assert that, even if she had been away from her husband overnight, she was an honest woman who had never been accused of adultery or fornication. Instead, as more proof of her disruptive behavior, they mentioned two occasions where she tried to drown herself in local wells, once at the convent of the Sisters of Saint Katherine. Fortunately, both times the 'good people' of Montpellier prevented her. As a result of these disruptive behaviors, Ysabeau 'was defamed in the said town of Montpellier and other places there where people knew of her' as a 'person who is not very sensible with good discretion or natural sense' ${ }^{5}{ }^{6}$ So before she committed murder, Ysabeau was already recognized by her community as someone who might be a disruptive force. At this point, however, she had only damaged her marriages and threatened to harm herself.

In the end, Ysabeau's crime did not follow the pattern of her previous behavior, which made it unpredictable, so that her community could not have known she posed a danger to others. One day in April, she was in the solar of a house (not her husband's) when she called from the window to an eight-year-old servant girl who was passing by carrying bread and pastries for her master, Phot Ostarde. When the girl came to the window, Ysabeau picked up a pestle that was lying nearby and 'suddenly and as if insane and out of her good sense and natural discretion' hit the girl over the head. ${ }^{57}$ As with several other cases where a mad person killed someone who was not a relative, the letter on behalf of Ysabeau clarified that she did not have any hatred for the girl or any of her connections nor had she engaged in any arguments with them. These assurances were used to locate this crime as an aberration, one that certainly did not spring from a premeditated revenge. As a result, the murder of the unnamed servant girl, who was just going about her business and trusted her neighbors, was all the more troubling because

55 AN JJ 163 fo 130 no 229: 'en lostel de sa mere et avec ses autres amis tant de jour comme de nuit et comme paravant sans congie et voulente de son dit mari'.

56 AN JJ 163 fo 130 no 229: 'elle est diffamer en la dit ville de Montpelier et autre part la ou len a congnoissance delle' 'comme personne qui nest pas bien sensible de bonne discrecion ou sens naturel'.

57 AN JJ 163 fo 130 no 229: 'incontinant et comme aliene et hors de son bon sens et discrecion naturelle'. 
it was unexpected. Ysabeau's actions were unpredictable and endangered her community at large, not just her own life or her reputation.

In each of these cases of murder, the mad perpetrator violated expectations of safety that were in place due to kin relationships or neighborliness. Pierre le Bagnaudel's wife, Jehannecte Troppé's husband, and Pierre de Solente's son were all sleeping, trusting their family members would care for them. None of these relationships was described as unusually tense, except that the two Pierres and Jehannecte were known to have had episodes of madness previously. Similarly, Ysabeau Sarvallier's victim was going about her master's business, bringing home goods from the bakery, when she was called over to help a neighbor. Again, Ysabeau was known locally as a mad woman. However, much as Charles VI was allowed to govern the realm during his periods of sanity, Pierre, Jehannecte, Pierre, and Ysabeau were all allowed to continue in their usual roles despite the danger they ended up posing to others in their families or communities.

\section{Theft in Inappropriate Circumstances}

The second most common crime in letters for the mad was theft. ${ }^{8}$ The invocation of madness tended to appear in letters where people had chosen inappropriate targets for their thefts, again disrupting expectations of safety, this time of goods. The narratives also described thefts that provided no material benefit for the perpetrator, who either threw away the stolen goods or had no knowledge of where they had hidden them. In these letters, the use of the rhetoric of madness was a more subtle indication of popular considerations of folly and, compared to murder cases, a less dangerous lack of sense. ${ }^{59}$ However, some of these letters did represent the thief as threatening, shifting the terminology of madness from 'foolish' to 'furious', 'without good sense and understanding', and 'melancholy' ${ }^{60}$ In every case, the thefts described challenged communal expectations of who might steal from whom and why.

Many cases focused on the inadvisability of the particular theft committed. For example, a letter from 1428 described the actions of Marion Hodee, who stole from her master, the local captain of the guard. The relationship

$5^{8}$ This also follows the general pattern for remission letters as a whole. Theft made up $16 \%$ of total crimes in Gauvard's study. Gauvard 1991, vol. 1, p. 242, table 8.

59 See for example AN JJ 99 fo 173 v no 567 (in 1368); AN JJ 106 fo 173 no 318 (in 1374); and AN JJ 106 fo 184 V no $35^{2}$ (in 1374).

6 o See AN JJ 107 fo 193 v no 377 (in 1375); AN JJ 115 fo 52 no 114 (in 1379); AN JJ 188 fo 82 V no 163 (in 1459); and AN JJ 196 fo 192 no 307 (in 1470). 
between the thief and her victim was a hierarchical one, and in addition his role as captain of the guard made him a dangerous target for any theft. As the letter composers explained, Marion had little understanding and was as if an idiot or insensible' and she acted 'without thinking she was doing wrong, ${ }^{61}$ a characterization that in part sprang from her actions, which were clearly perceived as idiotic. The choice to steal from her employer was not well-considered, and it also raised fears that hierarchies might be challenged. In addition to the attempt to justify Marion's actions in terms of her lack of understanding, the letter explained that she was driven to steal from her master because her relative, Jehan Baptiste, wanted revenge on the captain for having dishonest relations with Jehan's wife. The complex social relationships involved in this narrative highlighted the difficulty of the situation for Marion. Her kinship with Jehan, a horizontal tie, led her to act against her master, with whom she had vertical ties. The whole situation arose because Marion's master had taken Jehan's wife as a mistress. Marion was exonerated, then, both because it was her kinsman's idea and because, being a simple and insensible woman, she did not know what she was doing was wrong. Indeed, as the letter explained, Marion was caught because she was witnessed throwing the goods she had stolen into the castle moat. The portrayal of Marion as mad held power because her crime could be recognized as ill-considered and lacking any personal benefit.

Many cases involving mad thieves present hierarchical relationships between the thief and his or her victim, suggesting these crimes were viewed as especially problematic. In a letter composed in 1387 , Guillorz de la Cayroze humbly requested the release of his son, Perym. The young man, who was only fifteen at the time, had been arrested under suspicion of theft from a merchant staying in the inn that Guillorz de la Cayroze maintained in Angiers. The letter began as a straightforward tale about a merchant who left his well-filled purse in a sack in his room. During his absence, the purse was stolen, and he accused the innkeeper's son of theft. If Perym had been guilty, stealing from a guest at his father's inn would have violated expectations of safety. However, at this point, the letter's narrative became more complicated. Perym, after undergoing torture in prison, confessed he had taken the purse. First he claimed it was in the bed in the chamber where the merchants were staying, but when the authorities looked for it there, their search was fruitless. Perym then denied having taken the purse until they began to torture him again, at which point he again confessed,

61 AN JJ 174 fo $68 \mathrm{v}$ no 163: 'poy sachant et qui est comme ydiote ou insensee'; 'non cuidant mesprendre'. 
providing them with a new hiding spot that again turned out to be empty. According to the letter, this wild goose chase continued for some time, and the money was never found. Guillorz used the remission letter to insist that his son should be released, 'considering the youth of the said Perym who is as if completely idiotic and does not have a good natural sense'. ${ }^{62}$

In Perym de la Cayroze's case, the composers of the remission letter constructed a complex narrative to explain why he should be released from prison. Unlike other letters that established the subject's madness from the beginning, here it was not raised until near the end of the letter. Instead, the letter began with a straightforward crime that only became troubling when the boy confessed. Through the structure of the narrative, it was Perym's many false confessions under torture that made his status as an idiot without good common sense believable. Aside from descriptions of Perym's own confessions, each of which was retracted after the torture was removed, nowhere does the letter admit Perym was guilty of stealing the money. In this way, the letter excused Perym on multiple levels. Other than his retracted confessions, there was no proof he had taken the money, and even if he had stolen it, his youth made such actions excusable, and his lack of sense made him immune to punishment.

Clearly sane thieves could and did also steal from their social superiors. However, as both of these cases indicate, the particularity of the relationships between thief and victim and therefore the potential damage to the thief's own livelihood or that of his or her kin due to the theft made these cases troubling. Both Marion Hodee's and Perym de la Cayroze's alleged victims had the power to pursue them. Both were suspects because they had access to the victims' belongings, but they also had much to lose by committing the theft. The crime itself could be construed as an act that violated Marion Hodee's and Perym de la Cayroze's positions in the community, as well as threatening their own or their family's livelihood. Perym's case simultaneously indicated the folly of the crime, which had already had an adverse effect on his father's business, and the foolishness of Perym, who confessed under torture to a crime that, his father insisted, he had not committed.

\section{Homicide Against Themselves}

Perhaps one of the most problematic targets of mad violence was the self. Indeed, as noted above, some of the letters about murder cited previous

62 AN JJ 130 fo 159 no 282: 'considerant aussi la jeuneses du dit pym qui est comme tout ydiot et na pas bon senz naturel'. 
suicide attempts as proof of the person's madness. With eighteen of the 155 letters, suicide was the fourth most common crime for which families mentioned madness as an explanation, which shifts away from the pattern for remission letters in general. ${ }^{63}$ Gauvard lists suicide as a mere $0.4 \%$ of the crimes committed in remission letters during Charles VI's reign, ${ }^{64}$ whereas suicide makes up almost $12 \%$ of the crimes committed by mad people. Again, these letters highlighted problems of identity, family, and community.

In his study of suicide in the Middle Ages, Alexander Murray found that 'a suicide, or suicidal thought or act, follows an event of social dislocation, whether from crime, disgrace, or financial ruin'. ${ }^{65}$ Many remission letters followed this pattern, describing a particular despair or an illness that brought on the decision to die. Suicide was considered both a religious sin and a civil crime in the Middle Ages. The Christian church, through the figure of Judas, informed people that suicides were damned for eternity. In medieval art, suicides were associated with the vice of Despair, usually paired with the virtue of Hope, first through the figure of Judas, and later with general suicidal figures, depicted either hanging from a rope like Judas or stabbing themselves with a knife. ${ }^{66}$ Theologians took up this concept and further developed it. Augustine, for example, in The City of God, argued that suicide was a violation of the commandment 'thou shalt not kill'. ${ }^{67}$ Thomas Aquinas, in his Summa Theologica, agreed that suicide was a sin. He expanded Augustine's evaluation of why, building on the idea that suicide violated this commandment, and arguing that suicide further violated natural love and charity, according to which man should love himself. Perhaps most significantly, Aquinas stated that 'every man is part of the community, so that he belongs to the community in virtue of what he is. Suicide therefore involves damaging the community.' ${ }^{68}$ The concept that suicide injured the community as a whole by harming one member provides an interesting perspective on medieval laws against it. The secular government helped the church to regulate suicides by confiscating the body and the goods of suspected suicides. The body would not only be buried in unconsecrated ground, but would also be symbolically executed

63 The third most common reference to madness in remission letters was as a victim of crime, which will be discussed in more depth below.

64 Gauvard 1991, vol. 1, p. 242, table 8.

65 Murray 1998, vol. 1, p. 317 .

66 See Barasch 1999 for an exploration of this phenomenon in art.

67 Augustine 1957, vol. 1, pp. 90-95, Book I.20.

68 Aquinas 1964, vol. 38, pp. 32-33, 2.2.64 Art. 5. 'homo est communitatis: et ita id quod est, est communitatis; unde in hoc quod seipsum interficit, injuriam communitati facit'. 
by being hanged as a murderer. The suicide's goods were confiscated by the crown, often leaving the remaining family destitute as well as destroying their reputation and standing in the community. ${ }^{69}$ As a result, suicide was a crime not only against the self and the community, but also against the surviving family.

Some remission letters focused solely on the dire situation of the innocent family members. In these letters, the suicide him- or herself played a small role, whereas the remaining family's size, economic needs, and innocence were highlighted..$^{70}$ While this focus worked, in the sense that it provided families with remission letters and a return of the confiscated goods, it did not exculpate the suicide completely. In an attempt to fully remove the stigma of suicide, many letter composers tried to establish that the suicide was not in his or her right mind when he or she died. Others went even further, arguing that the person had been under the watchful gaze of family members or neighbors, and that it was through cunning that he or she escaped from notice long enough to perform the suicidal act. For example, in 1421 Denis Sensigaut, a baker living in Saint-Marcel les Paris, had been ill for fifteen days of a 'sickness of heat'. According to the letter composed on behalf of his widow, Jehannette, he had received last rites before falling into a 'frenzy'. One day, when Denis had asked Jehannette to go to Paris to take his urine to a physician, he sent his nephew off to find him some milk and told the woman taking care of him to eat something. Having disposed of all his guards, Denis 'either by temptation of the enemy or as a result of the said frenzy and malady hung himself' by a cord he had tied to a stair in his house..$^{71}$

As with murder, suicidal actions taken by mad people were not considered to be characteristic. Thus, madness could be imagined as a second level of exoneration. Remission rhetorically erased the crime in the eyes of the government and, at least in theory, in the eyes of the community. Remission for an action during an episode of madness might further exonerate the individual in question, since the disease in addition to the letter erased the crime from the identity. This type of erasure was easier with a suicide than with a person who was still living, since there could be no serious repercussions to making a false claim of madness in the case of suicides. ${ }^{2}$

69 Cohen 1993, pp. 141-142.

70 See JJ 115 fo 82 no 172 ; JJ 173 fo 199 no 413 ; and JJ 174 fo $138 \mathrm{v}$ no 318.

71 AN JJ 171 fo 244V no 429, edited in Longnon 1878, p. 19: 'maladie des chaleurs'; 'se soit tant par temptacion de l'ennemi comme à l'ocasion de ladite frenoisie et maladie pendu'.

72 Alexander Murray, who also examined remission letters for suicides, has suggested that these claims of madness might be questionable in such cases. Murray seems to miss the point of 
Indeed, there may have been a tacit agreement within local communities that surviving relatives should not be punished for these crimes. ${ }^{73}$ However, the question of whether or not the individual was 'really' mad is not pertinent. Rather, the fact that composers chose to understand these crimes in terms of madness means it was a plausible narrative and that people could accept the label in the context in which it was presented. Indeed, because suicide was thought of as murder of oneself, the act was directly related to those murders of family members that were equally difficult to comprehend in normal terms. ${ }^{74}$

\section{Infanticide of Legitimate Children}

The excuse of madness was not required as an explanation for an infanticide case to be pardoned. However, some women's families claimed they were mad when they killed their babies. ${ }^{75}$ Generally such letters, like the letters about murder, were for particularly unusual types of infanticide, suggesting that these were more difficult cases to accept and integrate into a comprehendible narrative. There was a pattern of apparently acceptable and understandable infanticide. In these cases, women who were unmarried and generally poor became pregnant and had the baby, often while alone in their houses. These letters emphasized a number of fears that the new

letters of remission. He claims that a 'Letter of Remission, by definition, declared its beneficiary not guilty. Issued on a suicide's behalf it must prove he was not a suicide. So these letters should, in principle, be no exception to the obscurity intrinsic to suicide in French legal documents'. The trouble with his analysis lies in his insistence that remission letters were for people who were 'not guilty'. This was certainly not the case, since remission letters were in fact precisely for people who were guilty, but could be forgiven for their crime through the overarching grace of the French king. See Murray 1998, pp. 207-218.

73 Sara Butler suggests this might have also been true in English jury cases. See Butler 2006, pp. 268-275.

74 By $145^{\circ}$, remission for suicide had been phased out, regardless of whether the suicide was mad, suggesting either a more stringent attitude towards suicides on the part of the crown or less legal intervention on a local level. Diane Owen Hughes suggested this change in attitude might be due to humanism, which had a large contingent among the royal notaries and others in the legal profession. The humanist reading of the suicide of Lucretia was far more sympathetic than earlier Christian readings (personal communication). If so, this would suggest that the persecution of suicides fell off, rather than that it became more difficult to receive remission for such an act, but it would require considerably more research to substantiate any such assertion. 75 Remission for infanticide makes up $0.3 \%$ of Gauvard's study of crime in all remission letters, but as with suicide, it was more common as a crime committed by the mad, making up $3 \%$ of the total. Gauvard 1991, vol. 1, p. 242, table 8. For more on infanticide, see also Brissaud 1962. John Boswell 1988 suggests that people were more likely to abandon children than to kill them. 
mother experienced, including the anger of parents, an inability to care for the child, and the shame of being an unwed mother. Often the woman narrated her lack of knowledge of what to do with a newborn infant as the cause of the baby's death. These narratives are fascinating for the glimpse they provide of a certain level of understanding of and compassion for these women that was not recorded in the law codes. Infanticide was viewed as a capital crime, but clearly there were exceptions to this stringent rule that took into account the economic and social problems of poor young women..$^{6}$

The women described as mad in letters about infanticide do not fit neatly into this category of poor, unmarried, or widowed women. Rather, these were often married women with other children whose decision to kill their babies appeared inexplicable to their family and relatives. In addition, in most cases attributed to madness the child was not a newborn. The letter for Jehannette Voidié, discussed in detail in Chapter Three, represented her as a married woman with several children, who feared that her husband could not support another child. She killed the baby while taking him on a pilgrimage, when he was already several months old. ${ }^{77}$ The disparity between this case and that of a young, unmarried mother, whose baby died within hours of birth, is clear.

These two narrative models of the poor unmarried woman and the mad woman were not mutually exclusive. It was possible to imagine poverty and the shame of an illegitimate child combining to drive a woman out of her senses. A letter composed for Michelle Galande explained that her father died when she was eight, leaving Michelle and her mother destitute. To support herself and her mother, Michelle Galande sought alms, but ten years later, as an eighteen-year-old woman, she began to be solicited by 'some' to abandon herself, which 'because of her simplicity, ignorance, and the poverty and misery in which she lived' she did, and ended up pregnant. In the end, the composers of her letter explained, it was through her fear of dishonor and shame that she 'was therefore deprived of sense and understanding' and chose to bury the baby alive rather than admit she had given birth. ${ }^{78}$

Infanticide was an especially disruptive crime. Women's roles were often bound up in expectations of wifehood and motherhood, confirmed

76 I have traced the development of an 'acceptable' narrative of infanticide in this period, which I intend to make the focus of further study. For more on this development, and on a parallel shift in the thinking of the theologian Jean Gerson, who called for a more mild penitence in cases of accidental infanticide, see Gauvard and Ouy 2001.

77 AN JJ 172 fo 239 no 430, edited in Longnon 1878, pp. 130-133.

78 AN JJ 221 fo 30 no 35: 'par sa simplesse et ignorance et la povrete et misere en quoy elle estoit'; 'estoit lors despournent de sens et entendement'. 
through the idealized figure of the Virgin Mary.79 The murder of a helpless baby ruptured expectations of safety and comfort, and the mother's role as murderer, rather than protector, highlighted the enormity of the act. Infanticide can be seen as an extreme version of the larger pattern of mad murders that violated the idealized image of the peaceful interior of familial relationships. While some forms of infanticide by poor, young, and unmarried girls, might be comprehensible, the killing of a legitimate baby was not.

\section{Bestiality}

Whereas infanticide was a crime that was gendered female, bestiality was a crime that was gendered male.$^{80}$ Like the other crimes examined here, it was possible to gain remission for bestiality without claiming to have been mad, but occasionally the letters include madness as an explanatory device. Bestiality was another crime against the self, the family, and the community, since it was a sexual act removed from the appropriate venue of the marriage bed. Much like infanticide, bestiality appears to have a conventional narrative, even though it appeared much less frequently in the remission letters. This narrative focused on the youth and unmarried status of the perpetrator, in much the same way as letters for infanticide. Generally the young man was described as a teenager, and the crime usually took place alone, most often with the mare that was pulling his cart, a sheep he was guarding, or a cow in the stables.

Estienne Perdereau's remission letter from 1481 told a fascinating tale of how youthful mistakes could come back to haunt a person later in life. According to his narrative, when he was thirteen or fourteen (around sixteen or seventeen years previously, as he was about thirty when he sought remission, and the perfect age to commit a crime, since he was on the border of adulthood and could not be held legally responsible ${ }^{81}$ ), he had taken a cart into the woods, pulled by a mare. While there, he was tempted by the 'enemy from hell' into trying to have 'carnal company' with the mare, since he had not yet had 'carnal company' with a woman. ${ }^{82}$ However, before he could achieve his 'evil desire', he saw Guillot Baillif, a neighbor of his master's, and

79 Indeed, other idealized mother figures in medieval religious art included the mothers who tried to protect their children in images of the massacre of the Holy Innocents. Presciutti 2015, p. 168; see also Presciutti 2011.

8o Strangely, although the first bestiality case I found dates from 1406, well within the range of Gauvard's study, she does not mention it in her own analysis of the letters.

81 The age of adulthood was fourteen for boys and twelve for girls.

82 AN JJ 209 fo 93v no 170: 'tempte de lennemi denfer'; 'compaignie charnelle'. 
'as soon as he saw the said Guillot he returned to his good memory'. ${ }^{83}$ Thus, Estienne had been out of his 'good memory', and therefore was associating his mental state with madness, when he attempted to have sex with the mare. Not only did Estienne never consummate his bestial temptation, as he explained, but he immediately went to the church of Notre Dame de Clery and confessed his sinful desire to a priest, who absolved him and gave him a penance that he completed 'as well as he could'. ${ }^{84}$ Estienne proceeded to get married and live an exemplary life until one day, as he explained, he refused to give a pair of shoes to Guillot Baillif, who conceived such a great hatred for Estienne that he accused him of bestiality to the local justice and had him thrown in prison. As Estienne took pains to demonstrate, his actions were not, in the end, damaging to himself, to the mare, or to the community. He 'returned to his good memory' before taking the ultimate step, immediately reconciled himself with the church, and a few years later married and became a respectable member of the community. Guillot Baillif, rather, appeared unsavory in Estienne's narrative, waiting for seventeen years before bringing the case to the attention of the local justice due to a grudge.

The question of who would be harmed by bestiality was addressed obliquely in another case. In 1406, the seventeen-year-old Piot le Pele had been living for a year as a servant of the family of Piot Pichon, during which time he slept in the stable with the cows. Note that, at seventeen, Piot le Pele was too old to be considered a child, and therefore would be held accountable for his actions. Instead, the letter noted immediately that Piot le Pele was 'mad and out of all memory'. ${ }^{85} \mathrm{He}$ 'was tempted by the enemy combined with his insensibility such that he had carnal company and habitation with this cow'. ${ }^{86}$ Significantly, it was his mistress and her daughters who saw him do this and spread the gossip around the community, highlighting the dangers of bestiality as a crime against the community. The unmarried daughters of Piot Pichon were troubled by the actions of Piot le Pele. Indeed, perhaps it would have been more easily reconciled had he sought sexual release from one of them. After all, confession manuals saw fornication as a less problematic sexual sin, and some city governments in Italy explained

83 AN JJ 209 fo 93v no 170: 'mauvaise voulenter'; 'incontinant quil apperceut ledit guillot revien a son bon memoire'.

84 AN JJ 209 fo 93v no 170: 'au mieulx quil a peu'.

85 AN JJ 160 fo $264 \mathrm{~V}$ no 372 : 'fol et hors de toute memoire'.

86 AN JJ 160 fo $264 \mathrm{~V}$ no 372 : 'fu tempte par lennemy avec son insensibilite quil ot compaignie et habitacion charnelle a ycelle vache'. 
their decision to allow prostitution by justifying it as an alternative to other types of sexual deviance. ${ }^{87}$

In both of these cases, the men were young and had not yet had 'carnal company' with a woman. Their status as unmarried youths made their sexual crime less dangerous, but they were still threatening the morality of the community. The narratives of their remission letters turned attention to the questionable actions of their accusers. Guillot Baillif did not register a complaint until he had another reason to be angry with Estienne Perdereau. Indeed, Estienne, whose madness was temporary and did not even lead to the consummation of his misplaced desire, had confessed to his sinful thoughts immediately, going through the appropriate channel of the parish priest. Similarly, Piot le Pele, who was known to be 'fol', was witnessed by the women of the household, who chose to gossip about him in the community, thus spreading the problem further. Unlike Estienne, Piot did not seek out confession, and he had carried through with his desire. However, Piot's madness was not described as a temporary state, but as a long-term problem.

\section{Arson}

According to the customary law books of Normandy, mad people must be kept chained up or under guard specifically to prevent them from setting fires ${ }^{88}$ Interestingly, although this seems to be a perceived danger in general terms, it appears in only nine remission letters as a crime committed by mad people. Sometimes the letters merely described the arsonist in question as 'simple' or out of their senses due to excessive drunkenness, but occasionally fires were set by people who are described as emphatically out of their minds. Again, the crime appeared particularly troublesome because it attacked the community the mad person ought to defend. Indeed, some of the narratives were about people setting fire to their own homes or barns. This particular crime highlighted the fear of mad people as disruptive members of the community, since fires in medieval villages (especially in regions where wood and wattle were used as building materials) would have been highly damaging and uncontrollable.

In 1379, for example, Guille de la Barre, a wealthy man, began to suffer a reversal of fortune. He lost so much that he had displeasure in his life and 
wanted very much to be dead' ${ }^{89}$ However, it was at the moment when a court case was decided against him that Guille 'entered into a sickness such that he became totally altered and completely thus as if completely out of his senses' and began to say that God did not love him, since He allowed such terrible things to happen to him..$^{0}$ In his despair, Guille lit two of the beds in his own home on fire. Fortunately, the local officers of justice were apprised of the situation before too much damage was done. The extremity of Guille's actions was highlighted by his statement blaming God for his misfortune. His wanton destruction that threatened the entire town stemmed from his altered state, in which he could not be held responsible for his actions.

In some cases, arson attacks were not targeted at the person's own goods. One case in particular stands out for its complex narrative leading up to the fire. In 1427, Jahenne de la Boronne, wife of Guillaume and mother of four small children, including one who was only a month old, left her home to run some errands. The letter explains that she was 'light-headed', and 'stayed a long time'. When she returned home, her husband asked why she had left for so long, such that her youngest child was in a 'bad state'. Jehanne replied angrily that it was at the request of Estiennote, wife of Martin Raccavel, who she believed was having an affair with Guillaume. Seeing Estiennote nearby, Jehanne began to verbally attack her, asking 'why she had been false to her husband'. The two women began arguing with each other until Guillaume intervened, taking Jehanne home and beating her until she 'was calm enough'. He then left the house to tend their animals, at which point Jehanne, who was apparently not calm enough yet, 'left the said house as if completely despairing and out of her good senses' and burned down a house belonging to Estiennote that was worth six livres tournois..$^{91}$ This is simultaneously a typical narrative about jealousy and spousal infidelity and a shocking story about the actions of a woman who is out of her mind. Much like some of the suicide narratives discussed above, this letter exculpates Jehanne on multiple levels. Though her anger and despair about her husband cheating on her with their neighbor was understandable, her response was disproportionate and could only be explained if she were mad at the time.

89 ANJJ 115 fo 34 no 75 : 'a eu desplaisance de sa vie et voulsist bien estre mort'.

$90 \mathrm{ANJJ} 115$ fo 34 no 75 : 'entra en une maladie telement que il devint tout altere et tout ainsi comme tout hors du sens'.

91 AN JJ 174 fo 7 no 17: 'legier de teste'; 'longuement demouree'; 'mauvais estat'; 'pour quoy elle lui avoit forfait son mary'; 'fu assez apaisee'; 'se parti dudit hostel comme toutes desesperee ou hors de son bon sens'. 


\section{Mad Victims of Crime}

Mad people did not only appear in remission letters as the central figure of the criminal. Indeed, often they appeared as the victims of murder, who had to be killed because their madness threatened the lives of others. In many of these cases, they were perceived not as individuals who could be returned to their 'good reputation', but rather as dangerously and frighteningly uncontrollable potential criminals. However, sometimes (especially when they were related to their killers) they were simultaneously described as unfortunate victims of their madness.

Several letters involving mad victims follow a typical pattern of describing a bar brawl, explaining that the people involved had been drinking and eating before the violence broke out. Drunkenness was seen as exacerbating or even causing madness in these cases, and the letters describe a fight that was forced to turn deadly because of the victim's lack of sense or understanding..$^{22}$ According to these narratives, the mad were generally unpleasant people whose moments of madness were merely another negative aspect of their personalities.

A slightly more complicated narrative about a mad victim comes from a remission for Jehan Mondit in 1490. A mason, Jehan Mondit had been hired by Christophe Asse, seigneur de Rollière, counselor and chamberlain of King Charles VIII, to build a chapel in La Rollière, a small town near Parthenay. While he was living there, he got to know a certain Cappitaine Trigalle, 'a man of little understanding known as a fool'. One Friday evening, after eating and drinking in Parthenay, Trigalle arrived back in La Rollière where Christophe Asse and his men began to mock him and dance with him, laughing and exchanging 'joyous words'. Afterwards, the seigneur commanded his men to go to bed, leaving Trigalle alone. When Jehan Mondit returned to the courtyard alone, planning to go to bed, he saw Trigalle leaving the house, carrying a naked sword in both hands. Trigalle came running up to Jehan, 'swearing on the blood and the mother of Our Lord that he would kill him'. Jehan responded that he had no quarrel with Trigalle, and the mad man left him and ran towards the bridge, where he found Jehan Mondit's varlet and began again to swear and menace this new target. At this point, 'hearing the sound and the noise, knowing that the said Trigalle was mad and dangerous as truly he was', Jehan Mondit went to his varlet's aid, pulling the attention of Trigalle, who did not recognize 
him and was still armed with a sword. Trigalle managed to wound Jehan Mondit before he was finally able to get in a single hit on Trigalle's temple. Too late, Christophe Asse and his men arrived on the scene and took Trigalle back to the house, where the next day he died. ${ }^{93}$ This narrative gives us access to a moment when mockery of a reputed 'fool' went horribly awry. Jehan Mondit, who does not appear to have participated in the earlier raillery, is threatened nevertheless by the mad man. Trigalle appears as an amusing and entertaining fool early in the letter, then an uncontrollable blasphemer running around with a naked sword, unable to understand what he is doing. ${ }^{94}$

Even the murdered mad could appear as victims when they were family members rather than strangers, however. Just as mad people murdered family members because of their uncontrollable actions, so they could drive their family to kill them with the same behaviors. Around the year 1362, Margueroy la Marchande moved into the home of her nephew, Jehan Langlois, because she could not take care of herself. 95 It appears that she may have disagreed with that assessment, since according to the letter composed on behalf of Jehan Langlois, she tried to run away several times but he always brought her back. The letter explains that she ran away due to her 'foolish and simple desire and without any cause'. ${ }^{6}$ Finally, when she got up at two in the morning and left the house, Jehan followed her,

93 AN JJ 221 fo 32 no 39: 'homme de petit entendement repute comme fol'; 'joyeuses parolles'; 'juroit le sang et la mere de notre sieur quil le tueroit'; 'ouyt le bruit et la noyse sachant que ledit trigalle este fol et dangereux comme ala verite si este'.

94 It is unclear whether Trigalle was employed by Christophe Asse, but he does seem to fulfil a similar function to a court fool. The idea that fools employed by nobles could become violent and even that their violence could be part of their amusement value appears in Pierre de Fenin's memoires from the year 1423. In this incident, a number of fools were given twelve gold pieces. They put each gold piece in a large, silver drinking cup and then filled the cups with wine, saying whoever drank the wine should have the gold piece in it. Dalleret, the fool of Count Valeran of Saint-Pol, decided he would drink all twelve cups and have all twelve pieces of gold and proceeded to do so. When the other fools realized they had lost all their gold, they attacked Dalleret and beat him until he died. Fenin notes: 'for this reason we ridiculed them greatly' ('on fist mainte risée pour ceste besoingne'). Pierre de Fenin 1837, p. 202.

95 Whereas the Roman practice gave guardians to all mad people, French customals usually assigned guardians only to those insane from birth. Philippe de Beaumanoir used clear language to distinguish between these two different types of mad people, and it was only the fous de nature, those mad from birth, who were to be assigned guardians. Philippe de Beaumanoir 1970-1974, vol. 2, ch. 56, paragraph 1624. The Livres de jostice established similar rules for protecting the rights and privileges of the mad by placing them in the care of a guardian. Rapetti 1850, p. 59, IX.5. These customals assigned wardship to the relatives of the mad to deal with the complicated question of inheritance. See Pfau 2008, Chapter 2 and Ternon 2018.

96 AN JJ 99 fo 33 no 104: 'desa volonte fols et simple et sens aucune cas raison'. 
reportedly because he feared she would commit suicide by drowning herself in a fosse (a ditch or moat generally filled with water) or a well. He caught up with her next to a large fosse full of water and tried to take her home, but when she refused, he angrily hit her with a little stick four or five times, 'without blood and without wound and without doing anything else to her from which she might become ill nor have death come to her'. ${ }^{97}$ Regardless of how minor a reprimand he gave her, Jehan's aunt died about fifteen days later, and five years after that he and his wife and children sought remission for this act. Margueroy was not actively threatening anyone but herself, but her actions were inexplicable to her nephew and he used her mad behavior to justify beating her.

\section{Proofs of Madness}

In addition to representing the crimes committed by mad people as particularly damaging to their communal identity, many letters highlighted previous acts that indicated the person was mad to provide proof of madness. Not all letters indicate how long the individual was considered mad by others, but those that do range from a lifetime to the moments before the crime. The common medieval belief that mad behavior was instantly recognizable and, indeed, easily replicable by the sane, is significant for thinking about the meaning of madness in criminal cases. There were many ways to describe madness, but each one sought to provide proof, not only that the individual was unquestionably behaving as a mad person would, but also that this madness was either a long-standing issue in his or her life or a clear and real disturbance, not merely enacted conveniently at the moment of the crime. Because madness was acknowledged as imitable behavior, many of the letters provide case histories demonstrating that this was not a case of simulation. In doing so, they were responding to concerns expressed in both religious and legal discourse about the possibility of counterfeiting madness.

In the Bible, the ability to feign madness was represented as a positive way to avoid punishment. The event occurred during Saul's reign, after God had chosen David as the new king of Israel and sent an evil spirit to trouble Saul, who remained on the throne. Jealous of David, Saul attempted to have him killed, and David was forced into exile in the kingdom of Geth.

97 AN JJ 99 fo 33 no 104: 'sanz sang et sens plaie et sens autre mal luy fait dont elle deust estre malade ne mort ensuivant en sa personne'. 
In this case David used gestures coded as madness to fool his enemies into ignoring him, thus allowing him to escape:

And the servants of Achis, when they saw David, said to him: Is not this David the king of the land? Did they not sing to him in their dances, saying: Saul hath slain his thousands, and David his ten thousands? But David laid up these words in his heart, and was exceedingly afraid at the face of Achis the king of Geth. And he changed his countenance before them, and slipt down between their hands: and he stumbled against the doors of the gate, and his spittle ran down upon his beard. And Achis said to his servants: You saw the man was mad: why have you brought him to me? Have we need of madmen, that you have brought in this fellow, to play the madman in my presence? Shall this fellow come into my house? ${ }^{98}$

David's behavior demonstrates the ease with which madness could be copied. He merely stumbled and drooled on himself, and his enemies immediately interpreted him as 'insane' and 'furious', to give more accurate translations than the Douay-Rheims Bible provides. While in this case David's deceit allows him to escape an inappropriate punishment by a king who had lost God's favor, the Bible affirms the potential ease with which madness could be performed by the sane.

In his Coutumes de Beauvaisis, Philippe de Beaumanoir expressed concerns about the possibility that the accused could pretend to be mad in order to avoid legitimate punishment. This question would most likely arise, according to Philippe de Beaumanoir, when a mad person was perceived to have recovered from his or her madness and was released, at which point

one should examine considerably whether this was not done maliciously, for example if some people, when they had committed offenses, counterfeited being out of their senses [le hors du sens] in order to escape: and one should regard very closely what cause motivated the person

98 First Book of Kings 21:11-15. 'dixeruntque ei servi Achis numquid non iste est David rex terrae nonne huic cantabant per choros dicentes percussit Saul mille et David decem milia posuit autem David sermones istos in corde suo et extimuit valde a facie Achis regis Geth et inmutavit os suum coram eis et conlabebatur inter manus eorum et inpingebat in ostia portae defluebantque salivae eius in barbam et ait Achis ad servos suos vidistis hominem insanum quare adduxistis eum ad me an desunt nobis furiosi quod introduxistis istum ut fureret me praesente hicine ingredietur domum meam'. 
to commit the misdeed, and by this one will know if there was deceit [barat]. ${ }^{99}$

This fear of barat, which can be translated as a fraud, a deception, or a ruse, was querying the concept that madness was, in fact, a transparent phenomenon, and posed the theory that a person could imitate madness to avoid being punished for a real criminal act. For Philippe de Beaumanoir, the proof of madness would come from a close examination of what 'moved' the criminal, suggesting that a sane criminal would have different motivations than a mad criminal. According to this conception of madness, witnesses would not be able to tell from a person's actions whether or not he or she was mad. Instead, it would be necessary to consider the motives for the act to see whether or not the act itself was done due to madness.

Similarly, the author of the Livres de jostice, aware of the conception of madness as a cyclical disease, insisted that mad people who committed their crimes during a period of sanity should not go unpunished. According to the book,

the king says that it is necessary to take care with a mad person [desvé] who kills his father, whether he had done it in good sense or in madness [desverie]; and if he did it in good sense, he must pay for it. - And if you know certainly that he did it in madness [forsenerie], that he does not know what he does every day, and that he understands nothing, nor is there any suspicion against him, you can in a way cut his sentence, because he is tormented enough by his madness [desverie]: and he must always be well guarded [...]. And if it happens, as it sometimes does, that someone is mad [desvé] at one time and at other times is sane, and was sane at the moment when he did the deed, you should enquire diligently; and if you know it, you will not pardon him; and if it happens that you know that he did it by felony, it is right that he be tormented. ${ }^{100}$

99 Philippe de Beaumanoir 1970-1974, vol. 2, ch. 52, paragraph 1575: 'Et s'il revient bien en son sens, il doit estre delivrés de prison, et li siens rendus. Mes en ce cas se doit l'en mout regarder que ce ne soit fet malicieusement, si comme li aucun, quant il avroient fet les mesfès, contreferoient le hors du sens pour eschaper: si doit l'en mout regarder quele cause le mut a fere le mesfet et par ce savra l'en s'il i a barat'.

100 Rapetti 1850, p. 73 XXI.5: 'Et se l'en ne puet tenir aucun desvé, il doivent metre aucun consel et remède qu'il soient mis en prison, et issint le commende li rois. Et li rois dit que l'en se devoit prendre garde au desvé qui tue son père, s'il l'avet fet en bon sen ou en desverie; et s'il l'avet fet en bon sen, il le doit comparer. -- Et se tu sés certainement que il l'ait fet en forsenerie, qu'il ne sache qu'il face toz jorz, et qu'il n'entende riens, n'en i ait point de sopeçon contre lui, tu porras en une feintise estramper sa paine, quar il est assez tormentez de sa desverie: et totes voies le 
The author of the Livres de jostice took great care to distinguish between those who commit a crime while mad and those who commit a crime in 'good sense'. Unfortunately, there is no indication of how to 'know certainly' nor from whom one should 'enquire diligently' to 'know' that the mad person was sane at the moment of the act. It is likely that the question would have been directed to any witnesses of the crime, suggesting that, for the author of the Livres de jostice, madness was an externally recognizable state that could be judged by any witness. Knowledge of an individual's mental state would be difficult to prove beyond doubt, but a description of the person's performance of the criminal act could establish sanity or insanity.

Some letters sought to prove a person's madness simply by establishing that the condition had been recognized for a long time. So, for example, in 1378 the fifteen-year-old Jachete le Pernec was described as being 'of small understanding and natural sense' for her whole life before burning down her home in response to a dispute with a woman who lived with her. ${ }^{101}$ Similarly, Pierre Chambo 'called le Fol' was described as having always been 'like a complete idiot without having sense or discretion' when he got into an argument about paying the bill at a tavern in 1390 and ended up killing Pierre Audrieu. ${ }^{102}$ In these cases, madness was simply a part of the individual's identity, even becoming Pierre Chambo's nickname, and the composers of these letters saw no need to explain further how they knew these people were mad.

On the other extreme, some letters described a temporary madness that overtook the person for the moments before the crime and then disappeared. So, for example, in a 1489 letter about infanticide discussed in more detail above, the relatives of Michelle Galande explained that when she gave birth, she 'was for the moment deprived of sense and understanding' and buried her baby alive in a ditch. ${ }^{103}$ Another case of temporary madness had a clear external cause. Clement Marie took care of his seventy-year-old uncle Michiel who was unable to walk. One evening they got into an argument and Michiel hit Clement over the head with a stick, stunning him so that he did not know what he was doing when he hit his uncle back, giving Michiel a

doit l'en bien garder [...]. Et s'il avient, comme aucunes foiz, que aucuns sunt desvé une foiz et autre foiz sont sein, et fust seins en celui point où il fit le fait, tu l'enquerras diligement; et se tu le sés, tu ne li pardonras pas; et s'il est issit que tu saches qu'il l'ait fait par félonie, droiz est qu'il soit tormentez'.

101 AN JJ 114 fo 7ov no 147: 'de petite cognoissance et senz naturel'.

102 AN JJ 140 fo 83 no 67 : 'comme tout ydiote non aiant senz ne discrettion'.

103 AN JJ 221 fo 30 no 35: 'estoit lors despournent de sens et entendement'. 
wound from which he later died. ${ }^{104}$ In 1364, a temporary madness overcame Jehan Razochez, a baker who was angered by the taxes he had to pay. His anger was so intense that he was described as 'maddened by grief' when he blasphemed in front of the town's mayor. ${ }^{105}$ These cases of temporary madness also required no further explanation and relied on the extremity of the moment described to prove the person was truly mad.

When the madness was neither lifelong nor momentary, letter composers often chose to describe previous episodes of what they considered mad behavior in order to provide proof that the madness was real. Some relied on behaviors universally acknowledged to be unacceptable to create a pattern of madness that would be easily recognizable as inappropriate without elucidating the individual's patterns of behavior before becoming mad. Attempted suicide is one of the most commonly used referents in these cases. These were almost always efforts to throw oneself into a well or a ditch to drown. To list a few cases already described above, Pierre de Solente's family feared he would commit suicide, and after he killed his son his wife found him attempting to drown himself in a river. ${ }^{106}$ Similarly, Ysabeau, daughter of Raymon Sarvallier, tried to throw herself into two different wells around town, including one at a convent. ${ }^{107}$ Margueroy la Marchande's nephew feared she would drown herself in a fosse or a well, though it is unclear whether she actually had that intention. ${ }^{108}$ Jehanne, the wife of Chrestien Bolu, decided to drown herself and her children in a small river at the bottom of her garden, though in the end she only drowned one of them. ${ }^{109}$ Jehan le Vignon attempted to throw himself in a well and kill himself, but his wife (whom he later murdered) prevented it. ${ }^{110}$

The story of Marion, wife of Jehan de Fresnes, drives home the link between suicide attempts and behavior that threatens the family. In 1415, Marion who 'previously had been harmed in the brain [...] and previously had been tempted to drown herself' sent her six-year-old daughter to the solar with an apple then followed her up the ladder with a cord and a knife. When she arrived, in a parody of motherly concern, she asked her daughter what

104 AN JJ 131 fo $39 \mathrm{v}$ no 69.

105 AN JJ 98 fo $36 \mathrm{v}$ no 113: 'forcenez de grief'. The next chapter considers in more detail the ways extreme emotions were understood in terms of madness to provide space for the resolution of disruptions in the family and community.

106 AN JJ 110 fo 125 no 108.

107 AN JJ 163 fo 130 no 229.

108 AN JJ 99 fo 33 no 104.

109 AN JJ 195 fo $268 \mathrm{v}$ no 1204.

110 AN JJ 78 fo 145 no 262 . 
she had in her throat. Her daughter replied that it was a piece of the apple she had eaten. Marion asked her to show it to her, and when her daughter did, Marion grabbed her and cut her throat with the knife. Afterwards, she used the cord to create a noose and tried to hang herself. However, there was a bale of straw underneath her on which she placed a foot and began to call for help. Two neighbor women arrived and found Marion and her daughter. ${ }^{111}$ Marion's earlier attempts to kill herself provide context for understanding her murderous attack on her daughter.

Another case also demonstrates this link. Jacquet Morniet had been ill for a time when he killed his brother's wife Jehanne, who lived with him and his brother in their extended household along with their parents and children. After picking up a pestle and hitting her over the head, Jacquet ran out of the house 'wishing and attempting to go throw and drown himself in a well,' but his brother stopped him. ${ }^{112}$ In this case, Jacquet's suicide attempt emerged after he had already committed a terrible crime that disrupted his household. Perhaps because suicide was viewed as such a departure from acceptable behavior, it could be used as a clear indication of madness.

Nakedness and running through the fields were also considered general behavioral signs of madness. Pierre de Solente ran out of his house 'completely naked' after killing his son. ${ }^{113}$ Jehan Massetirer also 'got up from his bed completely naked' and fled the house to throw himself in a well. ${ }^{114} \mathrm{Jehan}$ Cavrignon also got up from his bed 'completely naked being in his chemise' and set fire to his father's home and outbuildings. ${ }^{115}$ In some ways, this concept drew from medieval literary depictions of madness. The idealized chivalric knight in French literature is constantly engaged in a performance of his identity, according to Susan Crane. ${ }^{116}$ In madness, these performances of civilized identity are transformed into performances of bestial savagery. Yvain, for example, is driven mad by the loss of his lady's love. ${ }^{117}$ Yvain reverts to animalistic behavior, living naked in the woods and eating meat raw. His behavior is the extreme antithesis of ideal courtly behavior, and he is

111 AN JJ 169 fo 17 no 26 : 'autrefoiz avoit este blecee ou cerveil [...] et dont autreffoiz elle avoit este temptee de soy noyer'.

112 AN JJ 188 fo 102 no 203: 'voulant et tendent a soy aler gecter et noyer en ung puiz'.

113 AN JJ 110 fo 125 no 108: 'tout nu'.

114 AN JJ 146 fo 65 no 129: 'il se leva de son lit tout nu'.

115 AN JJ 204 fo 6v no 13: 'tout nu estans en son chemise'.

116 Crane 2002, pp. 107-139.

117 Chrétien de Troyes 1994, p. 274. Lines 2805-2809: 'El chief, si grant quë il forsenne;/Lors se desschire et se despenne/Et fuit par cans et par valees,/Si laisse ses gens esgarees,/Qu'il se merveillent ou puet ester'. 
only recognizable through the scars on his body that indicate his former status as a knight who fought battles and won tournaments. ${ }^{118}$ This loss of love leading to loss of sanity and a reversion to bestial behavior became a common pattern in later romances. ${ }^{119}$ The image of the relationship between insanity and bestial behavior, or of madness as a return to nature, made a clear connection between wildmen and the mad people in romances who, through losing their senses, lose their civility. Joyce Salisbury notes that wildmen fulfilled a particular function in medieval thought, arguing that the 'concept of a negative human, one who embodied everything humans did not, must have presented a strangely comforting figure because it threw into focus precisely those qualities that defined humanity: rational thought, social behavior, cleanliness, clothing, etc'. ${ }^{120}$

Both suicide attempts and public nudity were universally recognized as disruptive and inappropriate behavior. However, many letters described much more specific, focused, and personal disruptions, as is clear from the case of Jehan de Moustier whose narrative is discussed at the opening of this chapter. Similarly, before murdering her husband, Jehannecte Troppé began exhibiting behaviors viewed as disruptive by her family and friends, destroying her household goods and scattering flour around the floor. ${ }^{121}$ In general, in composing these letters, family and friends tended to focus on describing earlier behaviors that did not fit into their understandings of normal actions to contextualize the criminal act as an aberration.

The types of crimes committed by people described as mad, as well as the roles played by mad people as causes of crime or victims of crime, provided an image of madness as a disruption of kin and communal values and norms. The victims of mad crimes were often family members or neighbors with whom the mad person and his or her family had previously lived in harmony. The significance of the crimes committed by people who were believed to be mad lay not as much in the actual act but in the victims of those acts. Even when mad people caused a crime to occur, they were implicated in that crime specifically because of their inability to conform to expected patterns of behavior and because that inability threatened their family and community. These crimes were troubling because they disrupted accepted

118 Chrétien de Troyes 1994, pp. 280-282.

119 Mary Frances Wack has written an excellent book about medieval medical and literary ideas about lovesickness, which is distinct from (although related to) madness. See Wack 1990. 120 Salisbury 1994, p. 152. Richard Bernheimer had similarly argued that there was a 'psychological need' for a figure like the wildman in the Middle Ages. See Bernheimer 1952.

121 AN JJ 173 no 63 fo 33v. Edited in Le Cacheux 1907-1908, pp. 181-183. 
social codes, not because of the nature of the crime itself, but because the victim of that crime was someone or something that should not be targeted by the mad person. These remission letters sought to tell a story that embedded the particular moment of the crime in a narrative structure that could explain these ruptures as part of a general pattern of mad behavior. It is precisely through attempts to comprehend these misconceptions of the mad that these narratives can begin to allow a reconciliation between the mad person, or the mad person's family, and the community. By trying to explain the transgressions of the mad in comprehensible terms, the narratives provided a bridge to reconnect the kin and community ties ruptured through the particularities of the mad person's crime. The family's choice to seek a remission letter to advocate for the mad person was a particularly resonant act on his or her behalf. The next chapter considers the way the very kin and communal ties that had been threatened through the actions of the mad were reaffirmed through these letters of remission. 
